\title{
RESPONSE
}

\section{The Abolitionist Stance}

\section{Thomas Mathiesen}

Tagree with the criminologist Heinz Steinert in a communication to a recent issue of Kriminologisches Journal ${ }^{1}$ that some very important abolitionist gains were made in the 1960s and 1970s. This was indeed a period, as he puts it, of "major historical success". Partial abolitions of systems were carried out. For instance, in Norway, both the youth prison and forced labour systems were eradicated, causing a major drop in incarceration. In several countries, the number of prisoners fell and remained lower than earlier for quite some time.

Secondly, I agree with Heinz Steinert that we do not need to feel desperate or ashamed that we could not stop the strong wave towards increased punitive populism, media panics and rising prison figures, and their societal and political underpinnings, which were increasingly characteristic of the 1980s, 1990s and later. As he says, those of us who belong to the (admittedly vaguely defined) "abolitionist movement" have at least not provided justifications for "the new exclusionary regime" which recently has been on the rise.

But there is also more to be said. What does it mean to be an 'abolitionist'? Concepts such as 'abolitionism' and 'abolitionists' swirl around. Admittedly, I have made them swirl around myself. Why do I call myself an 'abolitionist'? The classical sociologist Max Weber gave us, if we are willing to accept a parallel, one way of looking at it, in his now famous use of so-called ideal types in historical studies. It seems that he conceptualized ideal types by making it clear what an ideal type is not. It is not an average, it is not a hypothesis and so on. So with 'abolitionism'. An abolitionist, whether a scientist, a teacher or a person practising his or her trade, is not a person who is preoccupied with what I would call system justification. He or she is not a person who is preoccupied with refining the existing.

But it is possible also to define abolitionism is positive terms; not only in terms of what it is not, but also in terms of what it is. I submit to you: Abolitionism is a stance. It is the attitude of saying "no". This does not mean that the "no" will be answered affirmatively in practice. A "no" to prisons will not occur in our time. But as a stance it is viable and important. When I wrote The Politics of Abolition in 1974, and again when I published the latest edition of Prison on Trial in 2006, I was certainly 
preoccupied with strategies of achieving concrete abolitions. But I was also preoccupied with fostering and developing an abolitionist stance, a constant and deeply critical attitude towards prisons and penal systems as human (and inhumane) solutions.

It is possible to get closer to the core of the abolitionist stance. It is a stance which goes beyond the parameters or conditions of existing systems. Systems such as the prison or the penal system are complex functionally interrelated systems. Therefore, if you criticize one aspect of, say, the prison system, you are immediately confronted with the 'necessity' of that aspect. For example, if you criticize the security regime, you are immediately confronted by the necessity of maintaining the regime in view of, say, public opinion. When something is said to be 'necessary', you should beware. Functionally interrelated systems are not inherently conservative, but grow conservative by our succumbing to the parameters of the system. The succumbing to all of the parameters is close to the non-abolitionist stance. The abolitionist stance goes beyond (some of) the parameters. For example, it is possible to say "sorry, but public opinion is not my concern", or perhaps better, "public opinion can be changed, or contains other and quite different components" (more about this below).

It is easy to succumb to all of the parameters. Many forces work in this direction. I have outlined some of them in Silently Silenced (2004). Social pressures in the workplace - you have to cooperate with people, share secrets with them, strike very informal, almost unnoticeable bargains with them, all of which compromise you. Hierarchical disciplinary pressures in the workplace - staying in line - operate in the same direction. Simply fatigue from everyday chores also does so. Imperceptibly your stance is altered into something more or less different from saying "no" to given arrangements. To be sure, we cannot and perhaps should not have an abolitionist stance to everything in the world. But we should have an abolitionist stance to things highly negative and vital politically speaking in our professional lives, and perhaps in our lives as human beings.

Is abolitionism a stance or a movement? There are probably variations nationally and internationally. In my country, Norway, I see at least some rudiments of such a movement, indeed despite the dark 1990s and early 2000s. To be sure, prison figures are increasing by leaps and bounds in a whole range of countries. We all know that. Judging from the media and from superficial opinion polls, there is wide support for the increase. We all know that, also. But there is wide concern and worry, in the professions and among segments of the population about "the new exclusionary regime", to use Heinz Steinert's apt term once again (Feest and Paul, 2008). There 
is also, more specifically, concern and worry about the use of prisons, perhaps especially against younger delinquents. The concern and worry, and the abolitionist stance, is not so apparent on the surface. The surface is covered by frightening media stories about terrifying murders and rapes, and about people being terrified by the stories. But under the surface layer there are more nuances. We have recent and solid empirical grounds for saying that it is a matter of distance and closeness. The closer you come to those who have committed unwanted acts, the more nuanced you become. A large scale Danish study, headed by the Danish criminologist Flemming Balvig, recently documented this in detail. ${ }^{2}$ Answering a general question about punishment, a representative sample of the Danish population massively wanted stricter punishment, longer sentences - as in all such public opinion studies. When more detailed information was given, however, the sample became much more nuanced. In cases when video tapes of staged court trials were followed by discussion groups, people turned relatively non-punitive.

Though very important, this can probably not be taken as a full scale proof of the existence of an abolitionist stance and certainly not of an abolitionist movement in a broad sense. More important is the concern you sense at large meetings with a critical focus outside the realm of television, especially those which forge networks where people support each other. When I waver, I get support from you and vice versa. Supportive networks are crucial. Through the years and up until the very present, I have attended and participated in organizing a very large number of open meetings on criminal and social policy. The organization KROM (The Norwegian Association for Penal Reform) still exists. We celebrated our 40th anniversary earlier this year, though the parallel Swedish organization vanished many years ago. The continued long life of the Norwegian organisation from turbulent 1968 till today, along with the early downfall of the Swedish organization represents an extremely interesting sociological question, which also contains very useful lessons for the future, but time prevents me from going into that. ${ }^{3}$ At any rate, during its 40 years of existence the Norwegian KROM has organized 38 large three-day conferences on penal policy. They are held in a particular mountain resort, giving historical continuity and a sense of belonging. Many generations of professionals and others have been covered by these conferences - altogether thousands of people - prisoners, ex-prisoners, social workers, lawyers, teachers, medical personnel, prison officers, people from the ministries and what have you. As opposed to most meetings of this kind, the conferences are cross-sectional, covering a wide variety of professions and trades. I want to emphasise in particular 
the mix of academics and (ex-)prisoners. This gives us two advantages. First, when academics are defined out as coming from the 'ivory tower', the prisoners are there to alleviate this with their practical experience. Second, when the prisoners are defined out as biased or prejudiced, the academics are there to alleviate this with analyses. Those who disagree with us are also present. Whereas in the 1960s and 1970s, the Prison Department avoided us, now they feel forced to come.

Debates are very heated. A main point is the struggle over definition of reality. Traditionally, the authorities have a monopoly on how to define what goes on in the relevant life world. This definition is challenged at the conferences. Cracks in the taken-for-granted definition of the situation, or even full fledged alternative and competing understandings of what life is like in our prisons and within the penal system, are fostered. Networks are created and maintained.

Other kinds of conferences have for a long time now drawn much larger crowds than first expected. This gives ground for optimism. A one-day public meeting in Stockholm a few years ago on prisons is an example. The organizers expected an audience of one hundred. Four hundred came and the meeting was a success and the crowd in fact said "no!" to some important elements in the development of Swedish prisons. An abolitionist stance surfaced.

We do not know what kinds of people come to the latter type of meetings. Perhaps they are not especially interested. If so, that is all right. Some will perhaps say that meetings of this sort are only dramatized and executed by fossils from the 1960s. I definitely think not - there are many young people about. An important sense of community, a 'moral community', sometimes appears. Some people have said to me, "I thought I was alone with my thoughts. But here are many others who view it in the same light!" Is this not a sign of a movement?

I do not want to idealize this. There are certainly obstacles. One obstacle, again, is television, instigating and 'sucking up' popular meetings, staging their own 'debates' as entertainment events. But we should not think of television and other media as constituting the only public space. Public space is a much more complex phenomenon - there are many alternative public spaces outside the realm of the mass media. The mass media, incidentally, have their 'mass' character as their Achilles' heel, unorganized and individualized as they are. Another obstacle is the everyday grind - you grow up, you get married, you get children, you get divorced, you have to go to work to earn a living and you dump down exhausted in front of the TV at the end of the day. But these events, at least some of them, also create vigour and life, and 
also at least some surplus of energy. A third obstacle is the neo-liberalism and market orientation of our time. But is that not in part what we are struggling against?

In others word, it is not impossible to nurture an abolitionist stance, a stance of saying "no!" and in the long run it makes a difference. It may contribute to what I would call turning points. The turning points of the past - the abolition of slavery, the abolition of the death penalty at least in some places, the abolition of the youth prisons in Massachusetts, the abolition of forced labour or what have you - should be scrutinized as examples for the future. What fostered them, what caused some of them to return under a different mantle? Turning points probably surface for structural, economic and political reasons. They become "ripe fruits", to use a Norwegian expression. But people act and channel them as they surface. An abolitionist stance of saying "no!" was certainly a part of past abolitions. It may be so again.

The vital importance of nurturing an abolitionist stance has been my main message today. It has also been my message to say that nurturing this stance is not impossible, but certainly possible. We are on the way. The International Conference on Penal Abolition, as well as The European Group for the Study of Deviance and Social Control and the Howard League are important participating venues. There are also others. Linking these together, which indeed takes place today, at this very moment, as the Howard League hosts the 12th Conference on Penal Abolition with many participants from the European Group is crucial.

But do not let us fool ourselves. It is not done with one stroke. It takes time and requires hard work. Again as Max Weber put it, this time towards the end of his famous lecture on Politics as a Calling in $1919,{ }^{4}$ admittedly in a context which may make many of us ambivalent today - he went on to talk about leaders and heroes and so on - but with a statement relevant to the abolitionist stance. I will first read it in German because it sounds so demanding in that language and then translate it into English: "Die Politik bedeutet ein starkes langsames Bohren von harten Brettern mit Leidenschaft und Augenmaß zugleich. Es ist ja durchaus richtig, und alle geschichtliche Erfahrung bestätigt es, dass man das Mögliche nicht erreichte, wenn nicht immer wieder in der Welt nach dem Unmöglichen gegriffen worden ware". And in English: "Politics is like strong, slow drilling in hard boards. It requires passion and an accurate eye at the same time. It is throughout correct, and all historical experience confirms this, that one never reached the possible, if there was not a continuous grasp for the impossible".

Thank you for your attention. 


\section{ENDNotes}

1 Presented July 23, 2008 at Creating a scandal - Prison abolition and the policy agenda, International Conference on Penal Abolition (ICOPA XII) at King's College London, UK. This paper emerges in part from an email exchange between abolitionists entitled "Abolitionismus. Einige Antworten auf oft gestellte Fragen" documented by Johannes Feest and Bettina Paul (2008) in Kriminologischen Journals.

2 (www.advokatsamfundet.dk, unfortunately so far only in Danish)

3 For a brief discussion of the history of KROM, see "Hva er KROM / About KROM - Past - Present - Future" (2000) at http://www.krom.no/hva_er_krom_more. php?id=89_0_26_0_C.

4 Published in 1919, printed in 1921 in Gesammelte Politische Schriften, subsequently in many other languages, including English and Norwegian.

\section{REFERENCES}

Feest, Johannes and Bettina Paul (eds.) (2008) "Does Abolitionism Have a Future? Documentation of an Email Exchange among Abolitionists", Kriminologischen Journals, retrieved from http://www.sozialwiss.uni-hamburg.de/publish/IKS/ KrimInstituteVereinigungenZs/Zusatzmaterial.html.

Mathiesen, Thomas (2004) Silently Silenced: Essays on the Creation of Aquiesance in Modern Society, Winchester: Waterside Press.

Mathiesen, Thomas (1990) Prison on Trial: A Critical Assessment, London: Sage. Mathiesen, Thomas (1974) The Politics of Abolition, London: Martin Robertson.

\section{About the Author}

Thomas Mathiesen, born 1933, is professor of sociology of law, University of Oslo, Norway. Mathiesen has done extensive research in prisons, and is also engaged in media sociology and the sociology of power. Six of his books are out in English, among them The Politics of Abolition (1974), Silently Silenced (2004) and Prison on Trial, third edition (2006). He is a co-founder of KROM - The Norwegian Association for Penal Reform, where he is still active. 